\title{
Media Pembelajaran dan Kurikulum Pendidikan Jemaat dalam Gereja Berbasis Online untuk Menghadapi Perubahan Globalisasi Abad ke-21
}

\section{Learning Media and Congregational Education Curriculum in an Online-Based Church to Face Globalization Changes in the 21st Century}

\author{
Medy Martje Lobang, ${ }^{1)^{*}}$ Yosua Feliciano Camerling ${ }^{2)^{*}}$ \\ 1) STT Levinus Rumaseb Sentani Jayapura \\ * Penulis Koresponsdensi: medy.yess@gmail.com \\ ${ }^{2)}$ Alumni Program Magister Sekolah Tinggi Filsafat Theologia Jaffray Makassar \\ *Penulis Koresponsdensi: yosuacamerling@gmail.com
}

Received: 15062020 / Accepted: 1406 2021/ Published: 15062021

\begin{abstract}
Abstrak
Di abad ke-21 ini, kemajuan teknologi mengalami perubahan dengan sangat cepat. Hal tersebut memengaruhi berbagai bidang kehidupan termasuk juga sistem pendidikan. Untuk itu, tujuan dari penelitian ini adalah untuk mengemukakan media pembelajaran dan kurikulum pendidikan jemaat untuk menghadapi perubahan globalisasi abad ke-21. Adapun metode penelitian yang digunakan ialah metode kualitatif deskriptif dengan teknik pengumpulan data melalui studi literatur dengan melihat fakta, pandangan dan berbagai sumber tentang media pembelajaran dan kurikulum pendidikan jemaat untuk menghadapi perubahan globalisasi abad ke-21 ini. Adapun hasil dari penelitian ini yaitu gereja berinovasi dalam pendidikan dengan memanfaatkan perkembangan zaman. Beberapa hal yang dapat dilakukan oleh gereja adalah menggunakan media pembelajaran online melalui ibadah live streaming dan pembelajaran online lainnya seperti WhatsApp, e-Learning, Google Classroom, Youtube maupun Zoom Meeting serta beberapa aplikasi sejenisnya seperti Google Meet, Microsoft Teams, Jitsi Meet dan lainnya. Kekuatan media pembelajaran ini dapat menciptakan inovasi pendidikan dalam gereja yang lebih kreatif, sistematis, terukur dan menyenangkan. Setelah itu, gereja perlu menyiapkan kurikulum pendidikan jemaat yang terdiri dari materi Pendidikan Agama Kristen yang berpusat pada Alkitab dan materi Pendidikan Umum yang tetap dapat dikaitkan dengan kehidupan rohani seperti materi tentang
\end{abstract}


kesehatan, etika berpakaian, public speaking, seks dalam pernikahan, keuangan dan lain sebagainya. Dengan demikian, gereja akan menikmati hasil yang baik dalam penguatan iman jemaat dan lebih bijak dalam menghadapi segala dampak negatif dari pengaruh perubahan globalisasi abad ke-21.

Kata-kata Kunci: Abad 21, Gereja, Kurikulum, Media Pembelajaran, Pendidikan.

\begin{abstract}
In the 21st-century, technological advances are changing very rapidly. This affects various areas of life, including the education system. For this reason, this study aims to present learning media and church education curriculum to face the changes of 21 stcentury globalization. The research method used is descriptive qualitative method with data collection techniques through literature studies by looking at facts, views, and various sources about learning media and church education curriculum to face the changes of 21 st-century globalization. The result of this research is that the church innovates in education by utilizing the times. Some things that churches can do are using learning media through live streaming worship and other online learning such as WhatsApp, e-Learning, Google Classroom, Youtube, Zoom Meetings, and several similar applications such as Google Meet, Microsoft Teams, Jitsi Meet, and others. The power of this learning media can create educational innovations in the church that are more creative, systematic, measurable, and fun. After that, the church needs to prepare a congregational education curriculum consisting of Bible-centered Christian Religious Education materials and General Education materials that can still be related to spiritual life, such as material on health, dress etiquette, public speaking, sex in marriage, finances, and others. Thus, the church will enjoy good results in strengthening the congregation's faith and be wiser in dealing with all the negative impacts of the changing effects of 21st-century globalization.
\end{abstract}

Keywords: 21st-Century, Church, Curriculum, Learning Media, Education.

\title{
PENDAHULUAN
}

Dengan kemajuan teknologi yang sangat cepat, berbagai bidang kehidupan berubah dengan cepat pula. Teknologi berubah, sarana kehidupan berubah, pola tingkah laku berubah, tata nilai berubah, sistem pendidikan berubah, dan berubah pulalah berbagai macam pranata sosial yang lain (Rusdiana, 2014, p. 34). Artinya, perubahan tidak dapat dihindari. Semua orang seharusnya menangkap perubahan itu agar dapat menjawab tantangan dunia dan masyarakat yang berubah.

Satu hal yang sering tidak disadari oleh gereja bahwa "Perubahan-perubahan ini tentu saja berdampak dalam seluruh segi kehidupan, termasuk pemahaman tentang 
Tuhan" (Budiono, 2018, p. 124). Jika gereja tetap dalam model pendidikan lama, sekalipun yang diajarkan adalah Alkitab yang tidak berubah, akan berdampak negatif dalam kehidupan iman jemaat, di mana Alkitab menjadi tidak menarik untuk didengar, kemudian akan ditinggalkan, dan jemaat akan diisi dengan hal-hal duniawi yang lebih menarik dan menjawab kebutuhan mereka di abad ini.

Apalagi sejak akhir Maret 2020 pandemi Covid-19 mulai merajalela di berbagai daerah dan Negara. Tanggung jawab-tanggung jawab baru harus kita dipatuhi (hidup sehat, menjaga lingkungan bersih, bekerja dari rumah, mencuci tangan, menggunakan masker, dan lain-lain; Tari, Selfina dan Wauran, 2020, p. 144). Gereja tidak lagi mengadakan ibadah secara langsung di gedung gereja karena dampak dari pandemi Covid-19. Ibadah gereja mulai dialihkan secara digital, melalui teknologi live streaming. Semua itu bertujuan untuk berpartisipasi dalam menghambat laju penularan Covid-19 yang bisa terjadi melalui kontak fisik (Dwiraharjo, 2020, p. 20). Untuk itulah, dibutuhkan sebuah media pembelajaran yang baru untuk menjawab perubahan globalisasi abad ke-21 ini.

Dalam penelitian yang diadakan oleh Zhang, Zhao, Zhou dan Nunamaker, menunjukkan bahwa penggunaan internet dan teknologi multimedia mampu merombak cara penyampaian pengetahuan dan dapat menjadi alternatif pembelajaran yang dilaksanakan dalam kelas tradisional (Zhang, et. al., 2004, p. 76).

Oleh sebab itu, penggunaan media pembelajaran online sebagai sistem pembelajaran yang baru, mendorong penyelenggaraan pembelajaran semakin efektif. Dengan media pembelajaran online dimungkinkan banyak pembelajaran yang diperoleh sehingga memberikan pelayanan kepada siswa lebih memuaskan. Idealnya pengajar dan pembelajar senantiasa mengakses berbagai informasi dengan cepat, bertanggung jawab dan sesuai harapan (Putranti, 2013, p. 141).

Selain media pembelajaran, kurikulum pendidikan dalam jemaat juga perlu menjadi perhatian dari para pemimpin jemaat secara khusus dalam menapaki perubahan globalisasi abad ke-21 ini. Menurut Hasugian, gereja perlu memberi perhatian serius berkenaan dengan pengembangan serta desain kurikulum pendidikan jemaat yang sesuai dengan kebutuhan dan konteks gereja lokal tertentu. la menambahkan bahwa penyusun kurikulum pendidikan jemaat hendaknya memahami dan memiliki keterampilan berkenaan dengan prosedur desain kurikulum sehingga program Pendidikan Kristen menjadi lebih akomodatif dan efektif (Hasugian, 2019, p. 52). Hal ini juga sejajar dengan pandangan Markus Oci yang menyatakan bahwa dalam mendesain kurikulum pendidikan jemaat, harus mengejawantakan, melestarikan keesistensi gereja di dunia ini (Oci, 2019, p. 13).

Untuk itulah, melalui penelitian ini, diharapkan dapat menjadi jalan keluar atau solusi kepada gereja untuk lebih berinovasi dalam menjawab dan memanfaatkan perubahan di abad ke-21 ini mengingat dampak perubahan yang secara positif dan negatif juga terjadi dalam kehidupan warga jemaat. Apalagi mengingat bahwa pendidikan dalam gereja merupakan suatu hal yang sangat penting karena menyangkut pertumbuhan rohani umat (jemaat). 


\section{TEORI}

\section{Media Pembelajaran}

Gereja dituntut untuk terus belajar (Simanjuntak, 2018, p. 1). Salah satu yang menolong pembelajaran adalah dengan menggunakan media. Media adalah segala bentuk dan saluran yang digunakan sebagai perantara atau pengantar informasi dari pengirim pesan kepada penerima pesan (Camerling, Lauled, Eunike, 2020, p. 10). Media di sini berfungsi sebagai alat bantu atau penolong dalam proses pendidikan, belajar dan mengajar, komunikator dan komunikan, guru dan siswa. Media akan menolong dalam proses komunikasi dalam pembelajaran.

Gereja berada di abad yang serba digital ini, abad yang dikenal dengan revolusi industri 4.0, dan salah satu hal terbesar di abad ini adalah Internet of Things (IoT), yang memiliki kemampuan super dalam menyambungkan komunikasi antara mesin atau perangkat dan manusia melalui jaringan internet. Gereja dapat memanfaatkan media di abad ini untuk proses pendidikan dan pembelajarannya.

Banyak manfaat yang bisa diambil dari kecanggihan alat komunikasi di abad ini bagi pendidikan. Guru misalnya bisa mendapatkan bahan ajar dengan lebih banyak melalui internet, guru dapat mengajar jarak jauh tanpa bertatap muka secara langsung dengan siswa, siswa dapat mengerjakan tugas dan mengirimkannya kepada guru juga tanpa bertemu secara fisik, guru dan siswa dapat berdiskusi tentang topik apa saja yang berkaitan dengan pembelajaran. Ada media-media sosial seperti Facebook (FB), twitter atau Whatsapp (WA) tempat bisa sharing materi pembelajaran, dan sebagainya yang sangat memudahkan proses komunikasi pendidikan.

\section{Kurikulum Pendidikan Jemaat}

Kata kurikulum berasal dari bahasa Yunani dari kata curir yang berarti pelari, dan curere yang berarti tempat berpacu atau tempat berlomba. Dari dua kata ini kurikulum diartikan sebagai jarak perlombaan yang harus ditempuh oleh pelari dalam suatu arena perlombaan (Wahyuni, 2015, p. 232). Dalam Undang-Undang Nomor 20 Tahun 2003 tentang Sistem Pendidikan Nasional dijelaskan bahwa "kurikulum adalah seperangkat rencana dan pengaturan mengenai tujuan, isi, dan bahan pelajaran serta cara yang digunakan sebagai pedoman penyelenggaraan kegiatan pembelajaran untuk mencapai tujuan pendidikian tertentu" (Depdiknas, 2003).

Kurikulum mungkin bukan bahasa yang umum dikenal dalam pendidikan dalam gereja. Kurikulum dianggap hanya pantas dipakai dan dibicarakan dalam pendidikan formal, dan dianggap tidak penting bagi gereja, karena "kurikulum awalnya merujuk pada sejumlah mata pelajaran yang diajarkan kepada peserta didik... yang erat kaitannya dalam upaya memperoleh ijazah" (Sanjaya, 2008, p. 46-47). Gereja tidak membutuhkan ijazah bagi jemaatnya, sehingga gereja tidak butuh kurikulum. Gereja tanpa kurikulum pendidikan adalah model pendidikan tradisional dalam gereja.

Benarkah kurikulum hanya berisi sejumlah materi pelajaran yang tujuan akhirnya adalah sebuah ijazah? Pasti tidak. Dari defenisi awal diketahui bahwa Kurikulum selain 
berisi materi pelajaran, kurikulum juga berisi rencana pembelajaran yang cakupannya begitu luas namun terarah. Campbell D. Wyckoff memandang kurikulum sebagai suatu perencanaan yang melaluinya proses belajar dan mengajar dapat secara sistematis dilakukan (Hasagian, 2019, p. 47). Itu berarti kurikulum pendidikan merupakan unsur penting dalam setiap bentuk dan model pendidikan (Wahyuni, 2015, p. 231), termasuk di dalamnya pendidikan dalam gereja karena dalam gereja ada proses Pendidikan Gereja tanpa kurikulum adalah gereja yang harus berinovasi.

\section{Usia Pendidikan Gereja}

Pendidikan dalam gereja bukan sesuatu yang baru, juga tidak mencontek pendidikan formal. Jika Pendidikan dalam gereja dihitung dengan usia, pendidikan gereja bahkan lebih tua dari pendidikan formal di sekolah, hanya bentuknya yang mungkin tidak terpahami.

Sisemora berkata, "Ever since God begin to reveal Himself to man, there has been an unfolding education movement directed toward adults" (Sisemora, 1970, p. 9). Diketahui melalui Alkitab bahwa sejak Allah mulai mengungkapkan diri-Nya kepada manusia, telah ada sebuah gerakan pendidikan berlangsung yang diarahkan kepada orang dewasa. Sepanjang catatan Alkitab, ada korelasi erat antara pendidikan orang dewasa dan pewahyuan Allah. Pendidikan kemudian berlanjut pada awal periode patriaki. Memang semua pendidikan pada masa itu adalah lisan dan kebenaran agama ditularkan dari mulut ke mulut. Nanti pada masa Musa barulah bentuk pendidikan tertulis dikenal, yaitu diperkenalkan Musa dalam pemberian sepuluh hukum dari Allah.

Setelah itu, pendidikan berlanjut melalui para nabi ketika mereka berkhotbah sebagai bagian dari proses pendidikan. Selanjutnya para rabi memperkenalkan pengajaran formal sebagai sarana pendidikan, dan Yesuslah yang kemudian membawa proses pendidikan ke puncaknya dengan membagikan dirinya sebagai guru (Sisemora, 1970, p. 9). Artinya dapat terpahami bahwa ketika gereja berbicara tentang pendidikan maka gereja sedang membicarakan kehidupannya sejak awal, tetapi faktanya gereja tidak focus memikirkan pendidikannya.

Pendidikan dalam gereja belum dapat berkompetitif dengan pendidikan formal yang maju pesat dengan inovasinya yang berkembang dari waktu ke waktu, padahal sesungguhnya pendidikan gereja hadir lebih awal dari pendidikan lainnya. Pendidikan dalam gereja seakan berjalan di tempat dan kalaupun berubah itu sangat sedikit, sehingga tidak berlebihan apa yang dikatakan bahwa aspek pendidikan dalam berbagai area di gereja telah lama sekali terabaikan (Gunawan, n.d., p. 1).

Tidak mau berubah atau mau berubah adalah pilihan. Pilihan itu memiliki konsekuensi. Yang pasti dunia tempat gereja berada adalah dunia yang sedang berubah dan mau tidak mau perubahan itu akan memengaruhi gereja dan semua yang hidup di dalam dunia, termasuk jemaat.

Hal yang dikritisi dari pendidikan dalam gereja bukan kepada pokok utama pengajarannya yaitu Alkitab, tetapi lebih kepada strategi dalam menyampaikan 
pengajarannya, dan dalam keberadaan gereja untuk mendidik secara lebih holistik. Pendidikan lama atau tradisional yang dipertahankan sebagai warisan pendidikan gereja dari zaman ke zaman, yang sepertinya dianggap cukup memuaskan, sudah selayaknya diinovasi seperti media pembelajaran, kurikulum pembelajaran, dan sarana prasarana pembelajaran.

\section{Dampak Abad 21 bagi Pendidikan Gereja}

\section{Dampak Positif}

Abad ke-21 ditandai dengan kemajuan teknologi yang luar biasa, yang berjalan sesuai dengan kemajuan ilmu pengetahuan. Kemajuan ini berdampak positif bagi pendidikan termasuk pendidikan gereja.

Pertama, pada pendidikan tradisional, narasumber satu-satunya dalam pendidikan adalah guru. Seorang guru yang bertanggungjawab akan bekerja keras untuk mempersiapkan materi pengajarannya melalui buku (pinjaman atau milik sendiri) dengan menggunakan waktu yang cukup lama untuk sebuah kualitas pengajaran yang baik. Murid hanya sebagai penerima ajaran (pasif). Tetapi di abad ini progres pendidikan begitu berbeda. Metode pendidikan yang dulunya "TCCO (Teacher-Centered-Content-Oriented) berkembang dengan konsep pembelajaran yang disebut Study-Centered Learning atau SCL, (Santosa, 2007, p. 33) dimana konstruktivis pedagogi tidak lagi bahwa guru mengirimkan pengetahuannya kepada siswa, tetapi siswa membangun pengetahuan itu sendiri. (Krishnan, 2015, p. 88-89).

Jika diaplikasikan ke dalam pendidikan gereja, hal ini dimanfaatkan untuk mengambil nilai positif di sana bahwa para pendidik di gereja (gembala, pendeta, hamba Tuhan) tidak lagi harus berjuang sendiri untuk mendidik jemaat, karena jemaat dapat memperkaya dan menambah informasi sendiri dengan mencarinya pada media teknologi digital di abad 21 ini, melalui internet atau world wide web (www). Para pendidik di gereja kini bukan sebagai narasumber saja, tetapi lebih sebagai fasilitator, bahkan "motivator" (Santosa, 2007, p. 34). Hasil yang diharapkan sehubungan dengan kualitas iman jemaat, bahwa jemaat akan semakin kokoh dalam iman karena pengetahuan terhadap Alkitab sangat banyak yang diterima, semakin meneguhkan jemaat dalam iman kepada Allah.

Kedua, dampak positif di abad ke-21 ini adalah pendidikan tidak terbatas dalam ruangan, dan waktu tertentu karena fasilitas teknologi digital abad ini mendukung pendidikan menembus ruang dan waktu (bagian ini akan dipaparkan dalam topic media pembelajaran). Ada kelas-kelas dunia maya yang dapat diciptakan. Pembelajaran menjadi sangat mengasyikkan.

Diaplikasikan kepada penddiikan gereja, hal ini dapat dimanfaatkan oleh gereja dalam mengajar jemaat, sehingga pendidikan tidak hanya terbatas pada hari khusus seperti dalam ibadah raya pada hari minggu melalui khotbah di jam yang sudah diatur (misalnya jam 09.00 pagi) di gedung gereja, atau pada ibadah lain yang diatur pada rumah jemaat, yang kesemuanya dibatasi oleh ruang dan waktu tertentu. Di luar 
waktu itu jemaat tidak menerima pengajaran. Artinya, terlalu sedikit waktu untuk jemaat diajar tentang Alkitab. Sebaliknya, melalui fasilitas teknologi digital, sangat banyak peluang waktu yang dapat dimanfaatkan untuk mendidik jemaat, sehingga iman jemaat pun dapat semakin kuat.

Ketiga, hal positif bagi pendidikan pada umumnya, termasuk pendidikan gereja dimana Pemenuhan kebutuhan akan fasilitas pendidikan dapat dipenuhi dengan cepat, (Jamun, 2018, p. 50) seperti tidak harus memperbanyak materi pembelajaran dengan mencopy-nya, tidak harus menggunakan ruangan yang besar untuk pembelajaran sekalipun jemaat yang diajar banyak. Contohnya di gereja jika pembelajaran dalam bentuk penyelidikan Alkitab (PA), materi PA tidak perlu diperbanyak (hemat biaya) cukup dengan mensharing materi melalui internet yang dapat dibaca dengan jelas oleh setiap jemaat; juga tidak perlu menyediakan ruangan khusus untuk jemaat duduk dalam kelompok PA, sehingga ketika kelompok itu cukup besar jumlahnya, maka PA tidak dapat dilaksanakan (tidak ada ruangan yang tersedia), karena ada media digital untuk sharing kelompok. Inilah beberapa dampak positif dari perkembangan di abad ke-21, abad tekhnologi digital bagi pendidikan gereja.

\section{Dampak Negatif}

Dampak negatif dalam abad ke-21, bagi pendidikan gereja juga ada. Tidak semua dapat ditulis di sini, hanya beberapa saja, untuk mempertegas bahwa pendidikan dalam gereja butuh inovasi agar tantangan yang berakibat negatif di abad ini dapat dicegah atau diminimalisir.

Pertama, pengalihfungsian guru dapat mengakibatkan guru tersingkirkan, dan juga menyebabkan terciptanya individu yang bersifat individual karena sistem pembelajaran dapat dilakukan dengan hanya seorang diri (Jamun, 2018, p. 51). Dengan demikian, menurut McLean \& Gibbs (2010) dan Wright (2011), tanggungjawab dan kekuatan bergeser dari guru, di lingkungan pengajaran tradisional, ke siswa, di lingkungan belajar yang berpusat pada siswa (Krishnan, 2015, p. 88-89).

Hamba Tuhan, pendeta, gembala yang dijadikan sebagai guru bagi jemaat mulai terabaikan. Jemaat bahkan merasa lebih pintar dari gembala atau pendeta mereka, tampil sebagai pengkritik pengajaran hamba Tuhan, meragukan kebenarankebenaran yang ada dalam Alkitab, karena banyaknya informasi yang dapat diperoleh secara mandiri, apalagi jika jemaat adalah orang yang haus pengetahuan dan masih skeptis terhadap Alkitab.

Kedua, hal negatif berikutnya bahwa informasi yang diterima jemaat sehubungan dengan pengajaran Kristen (Alkitab) begitu banyak, dan tidak semua informasi itu benar karena mungkin tidak sesuai dengan Alkitab. Gereja yang tidak berpacu dalam memberikan infomasi yang benar dan tidak berjuang membimbing jemaat dalam pengajaran yang sehat, cepat atau lambat akan melihat kehancuran 
iman jemaat yang tidak selektif, yang menerima mentah pengajaran yang "menyesatkan" mereka.

Ketiga, adalah munculnya kecanduan jemaat terhadap dunia maya seperti kecanduan terhadap permainan game online, jejaring social (Facebook, Whatsapp, Instagram), karena rata-rata subjek (orang) mengakses internet sebanyak 10 jam perhari (Hakim et al., 2017, p. 282). Tidak ada lagi waktu yang dimanfaatkan untuk belajar Alkitab, untuk terlibat dalam persekutuan Kristen dan gereja. Isi pikiran bukan lagi hal-hal yang positif dan membangun kehidupan iman, tetapi justru sebaliknya, bahkan kebenaran yang dipegang menjadi sangat relative, termasuk pokok iman Kristen yang diajarkan melalui gereja.

Keempat, munculnya karakter-karakter baru dalam diri pribadi seseorang yang tidak sesuai Alkitab yang menunjukkan degradasi moral, disebabkan jemaat selalu menonton atau melihat film atau tayangan kekerasan, ketidakjujuran, penyelewengan, situs-situs porno dan sebagainya secara bebas. Ismanto berkata, "degradasi moral di masyarakat sudah sangat merisaukan seperti maraknya perkosaan, kekerasan terhadap anak, seks bebas, dan perdagangan perempuan" (Sembiring, 2018, p. 23). Pengaruh negatif ini terjadi kepada orang dewasa, namun terlebih bagi anak-anak, remaja dan pemuda, dan "kenyataan degradasi moral tersebut di atas sudah mewabah seperti bencana yang membahayakan, bahkan orang percaya juga kena dampaknya" (Sembiring, 2018, p. 24).

Internet sebagai bagian dari lompatan teknologi di abad ke-21 ini sifatnya sesungguhnya netral, tergantung yang memanfaatkannya. Internet telah menyediakan hal-hal baik, hal-hal buruk, dan hal-hal tersembunyi. Orang-orang yang bermigrasi ke dunia internet harus berhati-hati dalam perjalanan dan petualangannya (Sianipar, 2018, p. 170). Kondisi-kondisi ini telah ditangkap oleh semua kalangan termasuk gereja, sehingga mau tidak mau gereja harus menginovasi pendidikannya, sehingga dapat menghadapi semua hal negatif dalam pengaruh abad ke-21 ini.

\section{METODE}

Adapun metode penelitian yang digunakan dalam penelitian ini ialah metode penelitian yang bersifat kualitatif. Metode penelitian kualitatif adalah suatu penelitian yang ditujukan untuk mendeskripsikan dan menganalisis fenomena, peristiwa, aktivitas sosial, sikap, kepercayaan, persepsi, pemikiran orang secara individu maupun kelompok. Beberapa deskripsi digunakan untuk menemukan prinsip-prinsip dan penjelasan yang mengarah pada penarikan kesimpulan (Hasmawati, 2020, p. 59). Untuk itulah penelitian ini bersifat kualitatif deskriptif untuk mengungkapkan atau memperoleh informasi dari data penelitian secara menyeluruh, luas dan mendalam (Sugiyono, 2008, p. 35).

Selanjutnya peneliti menggunakan teknik pengumpulan data melalui studi literatur dengan melihat fakta, pandangan dan berbagai sumber tentang media pembelajaran dan kurikulum pendidikan jemaat untuk menghadapi perubahan 
globalisasi abad ke-21 ini. Adapun prosedur penelitian dalam mendapatkan hasil penelitian yaitu, pertama, dengan mencatat semua temuan mengenai media pembelajaran dan kurikulum pendidikan jemaat yang didapatkan dalam literaturliteratur dan penemuan terbaru dalam jurnal. Setelah mencatat, langkah kedua, yang dilakukan adalah memadukan temuan dengan temuan-temuan peneliti mengenai media pembelajaran dan kurikulum pendidikan jemaat. Ketiga, menganalisis temuan dari berbagai bacaan berkaitan dan keempat adalah mendialogkan hasil bacaan dengan temuan mengenai media pembelajaran dan kurikulum pendidikan jemaat dalam gereja berbasis online untuk menghadirkan temuan baru. Terakhir, peneliti menyimpulkan seluruh hasil dan pembahasan penelitian. (Rantesalu, 2020, p. 46).

\section{HASIL DAN PEMBAHASAN}

\section{Media Pembelajaran}

Dari begitu banyaknya media pembelajaran yang ada, peneliti mendapatkan dua media pembelajaran yang dapat dijadikan acuan dalam gereja berbasis online untuk menghadapi perubahan globalisasi abad ke-21. Adapun kedua media pembelajaran tersebut ialah ibadah live streaming, dan pembelajaran online.

\section{Ibadah Live Streaming}

Ibadah live streaming atau ibadah yang disiarkan secara langsung melalui internet tidak dibuat untuk menggantikan pendidikan secara langsung dalam gereja, bukan untuk mengganti ibadah yang sudah diatur dengan baik melalui pertemuan langsung secara fisik, namun semakin memperluas jangkauan pendidikan bagi jemaat, secara khusus bagi jemaat yang sedang keluar kota atau daerah, sedang sakit dan harus berbaring di rumah, atau tetap harus bekerja pada waktu ibadah berlangsung bahkan digunakan oleh gereja dalam membina jemaat yang tidak sedikit dan tersebar di beberapa daerah dan negara (Okselviana, 2016, p. 5).

Tujuan awal ibadah live streaming adalah "untuk memfasilitasi jemaat" (Okselviana, 2016, p. 5) agar dapat tetap beribadah, tetap mendapatkan pengajaran Alkitab sekalipun jemaat karena berbagai alasan tidak dapat menghadiri ibadah secara langsung di gereja. Alasan lain berkenaan dengan panggilan gereja untuk menyebarluaskan Injil sampai ke ujung bumi (Mat. 28:19-20), dalam menggolkan visi penginjilan seperti "1 juta jiwa diselamatkan" (Okselviana, 2016, p. 15.) Dan seiring berjalannya waktu dan perubahan yang mengikuti alasan penggunaan ibadah live streaming terus berkembang, lebih khusus ketika terjadi situasi-situasi sulit bagi gereja untuk beribadah seperti biasa dalam sebuah ruangan.

Contoh yang nyata adalah terjadinya pandemi Covid-19, di mana pada pertengahan Maret 2020, pemerintah Indonesia melarang pelaksanaan ibadah dalam ruangan dan menyarankan untuk menggunakan fasilitas internet dalam beribadah. Gereja dipaksa untuk mengubah model pelayanan dengan ibadah secara digital, yaitu ibadah live streaming. Tujuannya "untuk berpartisipasi dalam menghambat laju 
penularan Covid-19 yang bisa terjadi melalui kontak fisik" (Dwiraharjo, 2020, p. 2). Ibadah seperti ini dapat tetap dipertahankan sekalipun kemudian pandemi Covid-19 berakhir. Karena ibadah live streaming adalah satu dari inovasi pendidikan dalam gereja di abad ini yang sesuai kebutuhan jemaat.

Tantangan bagi gereja dan pelaku pendidikan gereja termasuk seluruh jemaat adalah masuk dalam teknologi digital ini, memanfaatkannya, bahkan jika ini terasa sulit tetap harus memaksa pendeta dan jemaat belajar teknologi. Mau tidak mau harus bisa melakukannya (Dwiraharjo, 2020, p. 2), karena inilah zaman teknologi digital.

\section{Pembelajaran Online}

Sebelum terjadinya pandemi Covid-19 pembelajaran online sudah digunakan oleh dunia pendidikan sekular/formal melalui banyak media yang tersedia, seperti WhatsApp, E-Learning, Google Class, You Tube, maupun aplikasi zoom meeting atau sejenisnya seperti google hangouts meet, miscrosoft teems, jitsi meet, dan lain-lain. Kekuatan pembelajaran online ini "bisa mempertemukan dosen dan mahasiswa secara virtual sehingga proses belajar mengajar bisa tersampaikan dengan baik." (Dwiraharjo, 2020, p. 2).

Media pembelajaran online seperti ini dapat dipakai gereja dalam menginovasi pendidikannya karena media online adalah "perangkat pedagogi (alat bantu pendidikan), yang dimungkinkan melalui internet dan teknologi berbasis jaringan untuk memfasilitasi pembentukan proses belajar dan pengetahuan melalui aksi dan interaksi yang berarti" (Dwiraharjo, 2020, p. 2).

Melalui media pembelajaran online ini, dapat dilakukan diskusi Alkitab, sharing khotbah, atau sharing topic penting dan sedang hangat dibicarakan yang tentunya bermanfaat bagi jemaat, baik yang sifatnya Alkitabiah (berasal dari pokok pengajaran di Alkitab) maupun yang umum seperti "bahaya virus Covid-19", "gereja tetap kuat dalam masa pandemic virus covid-19," Protokol kesehatan", "Makna pederitaan global", "bidat abad ke-21" dan masih banyak topic pembelajaran lainnya yang dapat dishare melalui media pembelajaran online. Istilah yang marak dipakai adalah "webinar (Web-Seminar-seminar online) atau talk show online (temu wicara) dengan mengundang seorang pembicara dan dipandu oleh pemandu temu wicara (host). Salah satu contoh undangan webinar sebagai berikut. 


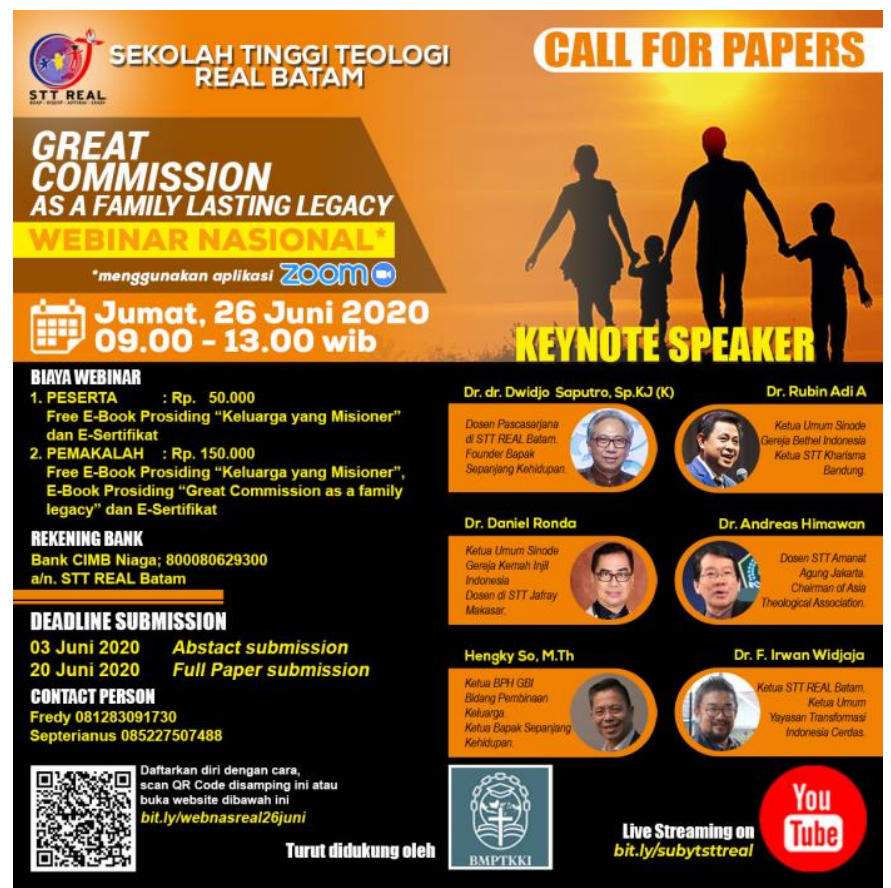

Gambar 1. Contoh Undangan Webinar

Kekuatan media pembelajaran seperti ibadah live streaming dan pembelajaran online ialah dapat dijangkau oleh semua orang di segala tempat sepanjang jaringan internet tersedia dengan cukup baik. Ini sangat menghemat biaya juga waktu untuk sebuah kualitas pendidikan. Namun di sisi lain pasti juga memiliki kelemahan. Kelemahan yang paling nyata adalah ketergantungan pada provider (Internal Service Provider-ISP) sebagai penyedia layanan sambungan internet. Kelemahan lain adalah ketidakpuasan jemaat dalam pelayanan dan pendidikan seperti ini karena tidak bertemu secara langsung, seperti yang menjadi keluhan jemaat di masa pandemic Covid-19 ini. Itu sebabnya sejak awal telah disinggung bahwa penggunaan teknologi digital ini dimanfaatkan bukan sebagai pengganti ibadah, pelayanan dan pendidikan gereja namun sebagai alat bantu yang semakin memperlebar dan memperkuat pendidikan pelayanan gereja bagi jemaat.

\section{Kurikulum Pendidikan Jemaat}

Di bagian ini akan dijelaskan secara rinci mengenai kurikulum pendidikan jemaat dalam gereja berbasis online untuk menghadapi perubahan globalisasi abad ke-21. Berikut penjelasannya.

\section{Pembuat Kurikulum}

Penanggung jawab dalam pembuatan kurikulum adalah pemimpin gereja setempat yaitu gembala. Namun gembala tidak dapat bekerja sendiri, karena pekerjaan pembuatan kurikulum bukan hal mudah. Sebaiknya dibentuk sebuah 
badan dalam gereja, yang terdiri dari para hamba Tuhan, beberapa pengurus jemaat (majelis) dan awam yang menguasai tentang pendidikan gereja.

Beberapa gereja yang mulai memikirkan hal ini kadang memberi nama badan tersebut dengan badan Pembinaan Warga Jemaat (PWJ) atau Badan Pembinaan Warga Gereja (PWG) yang yang salah satu tugasnya adalah mengupayakan pertumbuhan iman jemaat menjadi semakin dewasa melalui pengajaran, pelayanan khusus (kategorial), pemuridan, kelompok kecil dan pelatihan keterampilan hidup (Tarully, 2016, p. 4-6). Badan ini nantinya akan menyusun kurikulum pembelajaran dalam gereja secara utuh dan menyeluruh, dimulai dari kelas anak-anak seperti sekolah minggu, remaja, pemuda sampai kepada jemaat dewasa bahkan lansia. Diharapkan bahwa melalui kurikulum yang utuh dan menjangkau semua unsur dalam gereja, akan membuat pertumbuhan rohani dan kematangan spiritual jemaat seimbang dan mengalami progres kearah yang semakin baik.

Pembuat kurikulum akan berkoordinasi dengan gembala dan para hamba Tuhan dalam gereja lokal, sehingga kurikulum akan disesuaikan dengan pergumulan jemaat dan pergumulan pelayanan. Buku atau materi yang tepat dapat dibeli untuk menolong dalam menyampaikan materi pembelajaran. Koordinasi ini juga dilakukan dalam periode waktu yang ditentukan, yaitu diawal pembuatan kurikulum, sepanjang kurikulum berjalan dan diakhir semua penyajian kurikulum. Tujuannya untuk mengukur keberhasilan kurikulum pendidikan, mengevaluasinya dan mematangkannya dalam masa selanjutnya.

\section{Materi dalam Kurikulum}

Materi dalam kurikulum pendidikan gereja dibagi dua yaitu materi Pendidikan Agama Kristen dan materi Pendidikan Umum.

\section{Pendidikan Agama Kristen}

Materi yang pertama dan terutama dalam gereja adalah pendidikan agama Kristen yang berpusat pada Alkitab. Berkhof \& Van Till serta Kristianto menyatakan bahwa "Pendidikan Kristen harus dilaksanakan dengan Alkitab sebagai dasarnya, sebab standar kebenaran dalam Kekristenan adalah Alkitab." (Darmawan, 2016, p. 4142).

Alkitab sebagai materi pokok pengajaran dalam gereja dan jemaat tidak boleh diubah sekalipun kita berada dalam konsep inovasi. Namun dari dalam Alkitab ada begitu banyak materi yang dapat secara sistematis dan berkesinambungan diajarkan dalam gereja kepada jemaat. Ini yang tidak terpahami sehingga materi pengajaran dari Alkitab terkesan monoton, ada bagian-bagian Alkitab yang selalu dikhotbahkan dan bagian lain tidak, bergantung kepentingan hamba Tuhan yang menyampaian, dan sebagainya. Jemaat akhirnya tidak memahami Alkitab dengan baik sekalipun sudah menjadi Kristen bertahun-tahun atau sudah menjadi anggota gereja/jemaat belasan bahkan puluhan tahun. Ini yang terjadi dalam pendidikan tradisional gereja. 
Pendidikan Agama Kristen adalah tugas yang dipercayakan Tuhan bagi gerejanya di bumi. Tujuan pendidikan Kristen ini adalah membimbing umat atau jemaat agar mengenal ajaran-ajaran asasi kekristenan dan mempraktekkannya dalam hidup setiap hari sehingga kehidupan Kristen dan gereja menjadi benar dan menjadi saksi bagi dunia. Hanya saja, "Pendidikan agama Kristen yang merupakan tugas gereja, kini fungsinya sudah mulai kurang diperhatikan di dalam lingkungan gereja (Shefa, n.d., p. 1).

Ini bukan berarti pendidikan agama Kristen tidak diajarkan, tetapi tidak maksimal, sehingga belum menghasilkan perubahan perilaku hidup jemaat yang maksimal sesuai pengajaran Kristen yang diterima. Pengajaran hanya semacam kewajiban formal yang dilakukan tanpa diupayakan pengembangannya, sehingga "sudah seharusnyalah PAK di dalam gereja dikembangkan" (Shefa, n.d., p. 1).

Pendidikan Agama Kristen adalah proses pengajaran dan pembelajaran yang berdasarkan pada Alkitab, dan berpusat kepada Yesus Kristus. Pembelajaran ini ditujukan bagi pribadi-pribadi jemaat dalam semua tingkat usia untuk menuju kedewasaan iman, dan pengajaran berarti penyediaan proses pembelajaran yang efektif.

Dalam menyusun kurikulum Pendidikan jemaat, firman Tuhan juga mengatakan bahwa Tuhan mengangkat orang-orang khusus untuk menjadi rasul, nabi, pemberita Injil, gembala, dan pengajar untuk melaksanakan tugas yang penting tersebut (Ef. 4:11-13). Inilah kemampuan khusus mereka, yang dimaksimalkan dalam pengajaran agama Kristen (Alkitab dan iman Kristen) kepada jemaat dalam gereja.

Orang-orang khusus ini telah mendapat mandat untuk memberikan pemahaman Alkitab kepada jemaat dan gereja. Oleh karena itu, dalam pemberitaan firman tidak boleh kalah dengan perubahan yang terjadi bahkan harus memanfaatkan setiap perubahan yang terjadi. Memanfaatkan perubahan yang terjadi bukan berarti sekadar mengikuti arus dunia ini, namun "Gereja harus kembali pada pemahaman yang Alkitabiah mengenai pentingnya pendidikan dalam konteks gereja, seperti yang ditunjukkan dalam sejarah biblika. Gereja harus menanggapi panggilan dalam bidang pendidikan dengan lebih serius dibanding sebelumnya (Saputra, n.d., p. 1).

\section{Pendidikan Umum}

Konsep pendidikan umum dalam gereja belum sepenuhnya dapat diterima oleh gereja. Masih ada paradigma bahwa gereja adalah tempat rohani, dan hanya Alkitab yang boleh diajarkan dalam gereja. Mungkin ini pengaruh dari opini yang berkembang dalam umat Kristiani bahwa adanya eksistensi eksistensi dua alam yang independen, terpisah, tidak dapat direduksi bahkan alam atas lebih baik daripada alam bawah merupakan pandangan dualism (Sukamto, 2003, p. 140).

Semua materi yang tidak berbicara tentang Alkitab bukan ranah pendidikan dalam gereja. Gereja kurang memahami bahwa informasi-informasi yang dianggap 
"sekular" tersebut telah menjadi kebutuhan jemaat di abad ke-21 ini, abad yang disebut abad post-modern.

Sangat memprihatinkan jika setiap informasi yang tidak berhubungan dengan Alkitab, harus di cari "di luar" gereja. Materi pendidikan umum yang diajarkan dalam gereja disesuaikan dengan kebutuhan jemaat yang hidup dalam era globalisasi, era informasi, era IPTEK, dan era sangat cepat ini. Materi dalam kurikulum pendidikan gereja diatur sedemikian rupa sehingga bukan saja berisi materi yang sifatnya semata rohani (Pendidikan Agama Kristen), tetapi bisa juga dalam kurun waktu tertentu diisi dengan pendidikan umum (secular) yang tetap dapat dikaitkan dengan kehidupan rohani, seperti materi kesehatan (misalnya tentang penyakit kanker, jantung, cara hidup sehat), bisa juga tentang etika berpakaian, tentang public speaking, seks dalam pernikahan, mengelola keuangan dengan baik, etika berpakaian dan berbicara dan lainnya sebagainya. Diharapkan bahwa dari gereja, warga jemaat diajar lebih bijak dalam kehidupan ini, tidak tertinggal dengan semua kemajuan zaman namun tetap kuat dalam kehidupan spiritual.

\section{Model Kurikulum}

Kurikulum dalam gereja dapat dibuat sederhana, tidak harus seperti kurikulum pendidikan formal yang sering dibayangkan sulit dan gereja tidak membuatnya. Gereja dapat berpedoman pada metode pembuatan kurikulum pendidikan formal, di mana dalam kurikulum terdapat komponen-komponen yaitu tujuan, materi pembelajaran, metode, dan evaluasi (Nasbi, 2017, p. 318). Dalam bentuk sistem ini kurikulum akan berjalan menuju suatu tujuan pendidikan dengan adanya saling kerja sama di antara seluruh subsistemnya. Apabila salah satu dari variabel kurikulum tidak berfungsi dengan baik, maka sistem kurikulum akan berjalan kurang baik dan maksimal. Selain itu, dalam menentukan model kurikulum, perlu menaruh perhatian kepada pengembangan karakter (Astika dan Bunga, 2016, p. 63; Nuhamara, 2018, p. 93; Sidjabat, 2019, p. 73).

Kurikulum dalam gereja dapat dimulai dengan membuat tema besar sebagai visi gereja lokal. Dari tema besar ini ditentukan topik kecil yang dibahas dalam pengajaran setiap minggu atau bulannya. Tema pengajaran akan berkesinambungan sepanjang semester, atau sepanjang tahun. Melalui tema ini ditetapkan tujuan yang hendak dicapai, materi yang tepat untuk pencapaian tujuan, menggunakan metode apa saja dan akhirnya nanti dapat dievaluasi.

Tema pembelajaran akan menjadi tema sentral yang seragam kepada semua warga gereja/jemaat dalam kelompok jemaat secara umum, kelompok usia, kelompok gender, seperti anak sekolah minggu, remaja, pemuda, dewasa, lansia, para wanita, para pria, dan seterusnya yang ada dalam gereja, hanya disesuaikan dan disederhanakan dalam kelompok masing-masing (kategorial).

Kurikulum akan disajikan atau disampaikan bukan saja oleh gembala atau hamba Tuhan setempat, tetapi juga dapat disajikan oleh hamba Tuhan lain dari gereja lain/denominasi lain, dapat memakai kaum awam Kristen dari gereja lokal 
maupun dari gereja tetangga, yang menguasai materi pembelajaran yang diatur dalam kurikulum gereja. Tujuannya agar pengajaran dalam gereja berkualitas maksimal.

\section{KESIMPULAN}

Pendidikan dalam gereja bukan sesuatu yang baru, bahkan lebih tua dari usia pendidikan formal, karena sejak Allah mulai mengungkapkan diri-Nya kepada manusia, telah ada sebuah gerakan pendidikan berlangsung yang diarahkan kepada orang dewasa dan sepanjang catatan Alkitab, ada korelasi erat antara pendidikan orang dewasa dan pewahyuan Allah. Pendidikan adalah kehidupan gereja sejak awal.

Untuk itu, gereja perlu berinovasi dalam pendidikan dengan memanfaatkan perkembangan zaman. Beberapa hal yang dapat dilakukan oleh gereja adalah menggunakan media pembelajaran online melalui ibadah live streaming dan pembelajaran online lainnya seperti WhatsApp, e-Learning, Google Classroom, Youtube maupun Zoom Meeting serta beberapa aplikasi sejenisnya seperti Google Meet, Microsoft Teams, Jitsi Meet dan lainnya. Kekuatan media pembelajaran ini dapat menciptakan inovasi pendidikan dalam gereja yang lebih kreatif, sistematis, terukur dan menyenangkan.

Selanjutnya, gereja perlu menyiapkan kurikulum pendidikan jemaat yang terdiri dari materi Pendidikan Agama Kristen yang berpusat pada Alkitab dan materi Pendidikan Umum yang tetap dapat dikaitkan dengan kehidupan rohani seperti materi tentang kesehatan, etika berpakaian, public speaking, seks dalam pernikahan, keuangan dan lain sebagainya. Dengan demikian, gereja akan menikmati hasil yang baik dalam penguatan iman jemaat dan lebih bijak dalam menghadapi segala dampak negatif dari pengaruh perubahan globalisasi abad ke-21.

\section{KEPUSTAKAAN}

Astika, Made dan Selviyanti Sari Bunga. (2016). Hubungan Kompetensi Sosial Guru Krasten Terhadap Perkembangan Karakter Siswa: Tantangan Pendidikan Kristen Dalam Mencerdaskan Youth Generation. Jurnal Jaffray, 14(1), 63-76. https://ojs.sttjaffray.ac.id/JJV71/article/view/189/pdf_143.

Budiono, A. (2018). Inovasi Pengajaran Firman di Era Revolusi Industri 4.0. Prudentia, 1 (2), 124-134. http://e-

journal.sttbaptisjkt.ac.id/index.php/prudentia/article/view/11/15.

Brewster, D. (2005). Anak, Gereja Dan Misi. Jakarta: Compassion International.

Camerling, Yosua Feliciano, Mershy Ch. Lauled, Sarah Citra Eunike. (2020). Gereja

Bermisi Melalui Media Digital Di Era Revolusi Industri 4.0. Visio Dei, 2(1), 1-22. https://doi.org/10.35909/visiodei.v2i1.68.

Darmawan, I. P. A. (2016). Pendidikan Kristen di Era Postmodern. Jurnal Simpson, 1(1), 37-46. https://journal.sttsimpson.ac.id/index.php/Js/article/viewFile/3/2. 
Departemen Pendidikan Nasional. (2003). Undang-Undang Nomor 20 Tahun 2003 tentang Sistem Pendidikan Nasional.

Dwiraharjo, S. (2020). Konstruksi Teologis Gereja Digital: Sebuah Refleksi di Masa Pandemi." Jurnal Epigraphe, 4(1), 1-17. http://jurnal.stttorsina.ac.id/index.php/epigraphe/article/view/145.

Hakim, S. N., Raj A. A. (2017). Dampak Kecanduan Internet (Internet Addiction) pada Remaja. Prosiding Temu Ilmiah, 1, 280-284. ppmunissula.com/jurnal.unissula.ac.id/index.php/ippi/article/view/2200/1662.

Hasagian, W. J. (2019). Kurikulum dan Pembelajaran Warga Jemaat Dewasa di Gereja. Kurios, 5(1), 36-53. https://doi.org/10.30995/kur.v5i1.96.

Hasmawati. (2020). Kemampuan Menyimak Anak Melalui Kegiatan Bercerita (Studi Kasus Pada Taman Penitipan Anak Athirah Makassar). Jurnal Ilmu Teologi dan Pendidikan Agama Kristen, 1(1), 55-68. http://dx.doi.org/10.25278/jitpk.v1i1.463.

Iwamony, R. (2019). Awam Sebagai Subyek Bergereja. Diakses 12 Juni 2020. https://osf.io/z8w6m.

Jamun, Y. M. (2018). Dampak Teknologi Terhadap Pendidikan. Missio, 10(1), 48-52. http://jurnal.unikastpaulus.ac.id/index.php/jpkm/article/view.

Krishnan, S. (2015). Student-Centered Learning in a First Year Undergraduate Course. International Journal, 17(2), 88-89. http://www.ijlter.org/index.php/ijlter/article/view/353.

Nasbi, I. (2017). Manajemen Kurikulum: Sebuah Kajian Teoritis. Jurnal Idaarah, 1(2), 318-330. https://doi.org/10.24252/idaarah.v1i2.4274.

Nuhamara, Daniel. (2018). Pengutamaan Dimensi Karakter dalam Pendidikan Agama Kristen. Jurnal Jaffray, 16(1), 93-115. https://ojs.sttjaffray.ac.id/JJV71/article/view/278/pdf_171.

Oci, Markus. (2019). Implikasi Misiologi Dalam Pengembangan Kurikulum Agama Kristen di Gereja Lokal. Jurnal Fidei, 2(1), 81-99, https://doi.org/10.34081/fidei.v2i1.29.

Okselviana, A. D. (2016). Penggunaan New Media Sebagai Media Komunikasi Jemaat GBI Keluarga Allah Solo. Skripsi. Universitas Sebelas Maret Surakarta. https://eprints.uns.ac.id/25762/.

Pakpahan, Roida, Yuni Fitriani. (2020). Analisa Pemanfaatan Teknologi Informasi Dalam Pembelajaran Jarak Jauh Di Tengah Pandemi Virus Corona Covid-19. Jisamar, 4(2), 30-36.

http://journal.stmikjayakarta.ac.id/index.php/jisamar/article/view/181.

Pranoto, O. D. (2012). Gereja Sebagai Agen Pendidikan Kristen Anak Usia Dini. Jurnal Antusias, 2(2), 1-16. https://www.sttintheos.ac.id/ejournal/index.php/antusias/article/view/39.

Putranti, Nurita. (2013). Cara Membuat Media Pembelajaran Online Menggunakan Edmodo. Jurnal Pendidikan Informatika dan Sains, 2(2), 139-147. https://journal.ikippgriptk.ac.id/index.php/saintek/article/view/224/223. 
Rahayu, S. (2019). Manajemen Sarana dan Prasarana Pendidikan. https://www.academia.edu/27886838/MAKALAH_MANAJEMEN_SARANA_PRAS ARANA_PENDIDIKAN.

Rantesalu, Marsi Bombongan. (2020). Karakter Kejujuran dalam Gereja Masa Kini. Jurnal Ilmu Teologi dan Pendidikan Agama Kristen, 1(1), 43-54. http://dx.doi.org/10.25278/jitpk.v1i1.475.

Ronda, D. (2009). Kepemimpinan Model Gembala. Jurnal Jaffray, 7(2), 56-63. https://www.ojs.sttjaffray.ac.id/JJV71/article/view/28.

Rusdiana, H. A. (2014). Konsep Inovasi Pendidikan. Bandung: Pustaka Setia.

Sanjaya, H. W. (2008). Kurikulum dan Pembelajaran. Jakarta: Kencana Prenada Media Group. . (2006). Strategi Pembelajaran Berorientasi Standar Proses Pendidikan. Jakarta: Kencana Prenada Media Group.

Santosa, E. C. (2007). Penerapan Konsep Student-Centered Learning Dalam Pendidikan Tinggi Studi Kasus pada Bidang Studi Akuntansi. Jurnal Ilmiah Akuntansi, 6(1), 32-39. https://media.neliti.com/media/publications/75090-IDpenerapan-konsep-student-centered-learni.pdf.

Saputra, A. G. (n.d.). Refleksi: Pelayanan Pendidikan di Gereja. Bandung: Sekolah Tinggi Teologi Bandung. http://sttb.ac.id/informasi/artikel/462-refleksipelayanan-pendidikan-kristen-di-gereja.

Sembiring, N. (2018). Mengatasi Degradasi Moral Melalui Pembinaan Warga Gereja. Illuminate, 1(1), 22-24. http://www.sttbaptis-medan.ac.id/ejournal/index.php/illuminate/article/view/8/3.

Shefa, A. (n.d). Pengembangan Pendidikan Agama Kristen Dalam Gereja Khususnya Di Komisi Keluarga Muda. https://www.academia.edu/28181068/PENGEMBANGAN_PENDIDIKAN_AGAM A_KRISTEN_DALAM_GEREJA_KHUSUSNYA_DI_KOMISI_KELUARGA_MUDA.

Sianipar, Desi. (2018). Kepemimpinan Guru Pendidikan Agama Kristen (PAK) di Era Industri 4.0. Prosiding Seminar Nasional dan Call For Papers "Membangun Di Era Revolusi Industri 4.0". Program Pascasarjana Universitas Kristen Indonesia, Jakarta, p. 167-177. http://repository.uki.ac.id/829/.

Sidjabat, B. S. (2011). Mengajar Secara Profesional. Bandung: Kalam Hidup. . (2019). Kerangka Kurikulum Pendidikan Agama Kristen Berbasis Karakter di Perguruan Tinggi. Jurnal Jaffray, 17(1), 73-90. https://ojs.sttjaffray.ac.id/JJV71/article/view/314/pdf_183.

Simanjuntak, Junihot M. (2018). Belajar Sebagai Identitas Dan Tugas Gereja. Jurnal Jaffray, 16(1), 1-24. https://ojs.sttjaffray.ac.id/JJV71/article/view/279/pdf_167.

Sisemora, J. T. (1970). Adult Education In The Church. Redited by Roy B Zuck \& Gene A Getz. Chicago: Moody Press.

Sukamto, A. (2003). Pelayanan Gereja Di Indonesia Pada Era Reformasi. https://www.researchgate.net/publication/215599036. 
Sugiyono. (2008). Metode Penelitian Kuantitatif Kualitatif dan R\&D. Bandung: ALFABETA.

Syafaruddin., Asrul., Mesiono. (2012). Inovasi Pendidikan: Suatu Analisis Terhadap Kebijakan Baru Pendidikan. Medan: Perdana Publishing.

Tari, Ezra, Elisabet Selfina dan Queency Christie Wauran. (2020). Responsibilities of Students in Higher Education during the COVID-19 Pandemic and New Normal Period. Jurnal Jaffray, 18(2), 129-152. https://ojs.sttjaffray.ac.id/JJV71/article/view/525/pdf_202.

Tarully, Y. A. R. (2016). Peran PWG Dalam Meningkatkan Pertumbuhan Iman Jemaat. https://www.academia.edu/33269388/Peran_PWG_Dalam_Meningkatkan_OLEH

Valentia, V., Wibowo, M., Wondo, D. (2013). Konsep Perancangan Inferior Ruang Kelas Sekolah Minggu Gereja Pantekosta di Indonesia (GPdi) Sidoarjo. Intra Jurnal, 1(2), 1-17. http://publication.petra.ac.id/index.php/desaininterior/article/view/1595/1443.

Wahyuni, F. (2015). Kurikulum Dari Masa Ke Masa: Telaah Atas Pentahapan Kurikulum Pendidikan di Indonesia. Jurnal Al-Adabiya, 10(2), 231-242.

http://ejournal.kopertais4.or.id/mataraman/index.php/alabadiyah/article/view/2 792.

Zhang, Dongsong, et. al. (2004). Can e-learning replace classroom learning? Communications of the ACM, 47(5), 75-79. https://doi.org/10.1145/986213.986216. 